\section{Motivation and motivation-related factors and their relationship with burnout and engagement: A study of Iranian EFL learners}

\author{
Alavi, Seyed Amir \\ University of Sistan and Baluchestan, Iran (amir.alavi1989@outlook.com)
}

Abbasnia, Saleh

Mehregan Institute of English, Iran (saleh1074@yahoo.com)

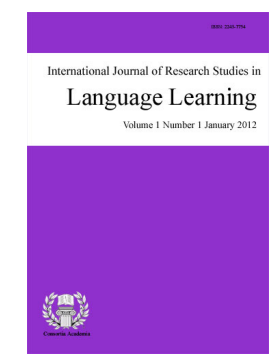

ISSN: $2243-7754$ Online ISSN: 2243-7762

OPEN ACCESS

\title{
Abstract
}

Motivation is a complex issue and several studies performed in this area have found several factors affecting it. Additionally, motivation and factors affecting it can be related to several other factors some of which still have not been subject to any empirical study. The purpose of the present study is to know how motivation and some motivation-related factors can be germane to burnout and engagement. The basis of the analysis is data collected from 95 language learners studying in language institutes in Iran. The analysis of data revealed that motivation and motivation-related factors are clearly linked to burnout and engagement.

Keywords: motivation; motivation-related factors; burnout; engagement; Iranian EFL learners 


\section{Motivation and motivation-related factors and their relationship with burnout and engagement: A study of Iranian EFL learners}

\section{Introduction}

Motivation is a well-studied issue in the field of language acquisition. The plethora of studies investigating motivation and its role in second language acquisition give testimony to the importance of this critical variable in second language teaching and learning. As to the Burnout, according to Langroudi and Pirouznejad (2013) this concept was first introduced by the psychoanalyst Freudenberger (1974) and has been defined as "to fail, to wear out, or to become exhausted by making excessive demands on energy, strength, or resources" (p. 159). However this concept was mainly limited to the human services domain, its application was later expanded to different domains by the publication of Maslach Burnout Inventory-General Survey (MBI-GS) (Schaufeli, Leiter, Maslach, \& Jackson, 1996). Finally it was the introduction of Maslach Burnout Inventory-Student Survey (MBI-SS) (Schaufeli, Martinez, Marques Pinto, Salanova, \& Bakker, 2002) which paved the way for the investigation of burnout in students.

Another variable in our study is engagement. As the opposite of burnout, the focus of engagement is human strengths and optimal functioning rather than weaknesses and malfunctioning (Shaufeli et al., 2002). Regarding burnout and engagement, Langroudi and Pirouznejad (2013) have successfully proven that burnout and engagement are significantly related to academic achievement, meanwhile, studies such as Gardner (1985a) have proven the relationship between motivation and achievement. Hence, the present study is interested in investigating the interplay of motivation, burnout, and engagement as three variables related to learners' achievement.

In spite of the theoretical claims made by those such as Crooks and Schmidt (1991; cited in Ellis, 2008) or Dornyei (1998) on the possible interface of motivation, burnout and engagement, no studies so far have investigated this relationship. Meanwhile, importance of these three variables for the success of language learners have been emphasised by researchers such as Dornyei (1998) and Langroudi and Pirouznejad (2013). The significance of this study stems from the fact that first; this study is investigating a possible relationship which so far has not been investigated. Second, while several ways have been introduced for increasing motivation among language learners, no studies so far have talked about ways of positively affecting learners' engagement and burnout, consequently, finding a relationship between motivation on one hand and burnout and engagement on the other may provide food for thought for language practitioners regarding ways of positively affecting engagement and burnout among language learners through the medium of motivation.

The present study has used translated versions of MBI-SS (Shaufeli et al., 2002) to measure learners' burnout, Utrecht Work Engagement Scale for Students (UWES-S) (Shaufeli et al., 2002) to measure learners' engagement, and Gardner's Attitudes/Motivation Test Battery (AMTB) (Gardner, 1985b) to measure learners' individual motivation, besides, different factors related to motivation have been measured using 12 subscales of AMTB and their relationship with burnout and engagement has been tested through statistical analyses.

Finally, answering the following research questions is the aim of the present study:

1. Is there any statistically significant relationship between Iranian EFL Learners' motivation and their burnout?

2. Is there any statistically significant relationship between Iranian EFL Learners' motivation and their engagement?

3. Is there any statistically significant relationship between subscales of AMTB and burnout of Iranian 
EFL Learners?

4. Is there any statistically significant relationship between subscales of AMTB and engagement of Iranian EFL Learners?

Following our research questions the following hypotheses were formulated:

1. There is no statistically significant relationship between Iranian EFL Learners' motivation and their burnout.

2. There is no statistically significant relationship between Iranian EFL Learners' motivation and their engagement.

3. There is no statistically significant relationship between subscales of AMTB and burnout of Iranian EFL Learners.

4. There is no statistically significant relationship between subscales of AMTB and engagement of Iranian EFL Learners.

\section{Review of Literature}

\subsection{Motivation}

If you look at different volumes on the issues in second language learning and teaching or even a reference book such as Longman Dictionary of Language Teaching and Applied Linguistics (Richards and Schmidt, 2002), you can see that none of them have provided a shorthand definition for motivation. Still from the literature on motivation, at least one conclusion can be drawn and as Richards and Schmidt (2002) have pointed out that is the multidimensionality of motivation. Generally there are two models for motivation, the first by Dornyei (1994) and the second by Gardner (1985a). Each model has tried to cover some aspects of motivation. In the following both models would be introduced in brief.

Gardner's Model for Motivation - Gardner was one of the pioneering scholars focusing on the issue of second language motivation, in his view motivation has four aspects: (a) a goal, (b) effortful behaviour to reach the goal, (c) a desire to attain the goal, and (d) positive attitudes towards the goal (Gardner, 1985a; cited in Root, 1995). Another aspect of Gardner's model is Motivational orientations. He has identified these orientations as integrative and instrumental. The former referring to a positive attitude towards the second language community and a desire to integrate with or adapt to that culture through the use of language and the latter referring to a more functional reason such as job promotion or language requirement (Gardner, 1985a; cited in Root, 1995).

In spite of the above mentioned orientations, Gardner (1985a) asserts that these orientations are different from learners' actual motivation. Meanwhile, he talks about different factors which affect second language learners' motivation. In Gardner's (1985b) work, several factors have been enumerated that affect learners' motivation; the factors are: interest in foreign languages, parental encouragement, motivational intensity, English class and English use anxiety, English teacher and course evaluation, attitudes towards learning English, attitudes towards English-speaking people, integrative and instrumental orientations, and desire to learn English.

To measure learners' individual motivation and the above mentioned factors, Robert Gardner and his Canadian associates developed Attitudes/Motivation Test Battery, a questionnaire which operationalizes the components of Gardner's model for motivation in measurable terms (Dornyei \& Csizer, 1998). AMTB is composed of 12 subscales each of which represent one factor related to motivation. In addition to these subscales, Gardner (1985b) introduces several composite scales which are measured by adding up some of these subscales.

One important composite scale introduced in Gardner (1985b) is "learners' individual motivation" which is 
Alavi, S. A. \& Abbasnia, S.

composed of three subscales of AMTB: (a) motivational intensity, (b) desire to learn English, and (c) attitudes towards learning English (Gardner, 1985b). Learners' individual motivation in Gardner's words has been defined as:

A complex of three characteristics which may or may not be related to any particular orientation.

These characteristics are attitudes towards learning the language, desire to learn the language,

and motivational intensity (Gardner, 1985a, p. 54).

Dornyei's model for motivation - Dornyei (1998) argues that motivation is multidimensional and still criticises Gardner for concentrating too much on its integrative aspects. Dornyei (1998) states that this excessive concentration on an integrative orientation to motivation is due to the fact that early motivation research was dominated by a psychological approach. He also argues that this multidimensionality stems from the multifaceted nature of language and its roles. Dornyei (1998) enumerates three roles for language; first, a communication coding system, second, an integral part of the individual's identity, and finally, a channel of social organisation. He goes on asserting that these unique roles of language differentiate second language motivation from the concept of motivation in general education (Dornyei, 1998). Based on a synthesis of static and dynamic conceptions of motivation, Dornyei (1998) defines motivation as a process whereby a certain amount of instigation force arises, initiates action, and persists as long as no other force comes into play to weaken it and thereby terminate action, or until the planned outcome has been reached.

According to Dornyei's model, motivation at language level comprises integrative and instrumental motivational subsystems. At learner level it comprises (a) need for achievement; and (b) self-confidence, where self-confidence itself includes language use anxiety, perceived second language competence, causal attributions, and self-efficacy. Additionally, motivation, at learning situation level, comprises course-specific motivational components, teacher-specific motivational components, and group-specific motivational components (Dornyei, 1994).

The following figure adapted from Dornyei (1994, p. 280) summarises all of the above mentioned components.

\begin{tabular}{|c|c|c|}
\hline \multirow{2}{*}{\multicolumn{2}{|c|}{ Language Level }} & Integrative Motivational Subsystems \\
\hline & & Instrumental Motivational Subsystems \\
\hline \multirow{2}{*}{\multicolumn{2}{|c|}{ Learner Level }} & Need for Achievement \\
\hline & & $\begin{array}{l}\text { Self-Confidence: } \\
\text { Language Use Anxicty } \\
\text { Perceived }\end{array}$ \\
\hline \multirow{11}{*}{$\begin{array}{l}\text { Learning } \\
\text { Situation } \\
\text { Level }\end{array}$} & \multirow{4}{*}{$\begin{array}{l}\text { Course-Specific } \\
\text { Motivational } \\
\text { Components }\end{array}$} & Interest \\
\hline & & Relevance \\
\hline & & Expectancy \\
\hline & & Satisfaction \\
\hline & \multirow[b]{3}{*}{$\begin{array}{l}\text { Teacher-Specific } \\
\text { Motivational } \\
\text { Components }\end{array}$} & Affiliative Drive \\
\hline & & Authority Type \\
\hline & & $\begin{array}{l}\text { Direct Socialization of Motivation: } \\
\text { Modelling } \\
\text { Task Presentation } \\
\text { Feedback }\end{array}$ \\
\hline & \multirow{4}{*}{$\begin{array}{l}\text { Group-Specific } \\
\text { Motivational } \\
\text { Components }\end{array}$} & Goal-orientedness \\
\hline & & Norm and Reward System \\
\hline & & Group Cohesion \\
\hline & & Classroom Goal Structure \\
\hline
\end{tabular}

Figure 1. Components of foreign language learning motivation (adapted from Dornyei, 1994, p. 280) 


\subsection{Burnout}

The concept of burnout was first introduced in the human services domain where people were engaged in some sort of professional activity (Schaufeli et al., 2002). Burnout has been characterized by its three components: (a) exhaustion that is measured by items referring to fatigue regardless of the sources of those feelings, (b) cynicism that refers to indifference or distant attitudes towards an activity, and finally (c) reduced professional efficacy due to the social and non-social aspects of professional (or educational) accomplishments (Schaufeli et al., 2002).

\subsection{Engagement}

According to Schaufeli et al. (2002) engagement is a positive, fulfilling, and work-related affective-cognitive state which is persistent and pervasive and is characterized by vigour, dedication, and absorption. Vigour itself is characterized by high levels of energy and mental resilience and willingness and ability to invest effort in one's own work. Meanwhile dedication has been characterized by a sense of significance, enthusiasm, inspiration, pride, and challenge. Finally the third dimension of engagement, absorption, has been characterized by being fully concentrated and happily engrossed in one's work (Schaufeli et al., 2002).

\subsection{Motivation, Burnout and Engagement}

Studying the literature on motivation, while one would recognise the depth and breadth of the work in this area, he or she would also be able to recognise that no studies so far have investigated the possible relationship between motivation, burnout, and engagement. This gap in the literature does not seem to be due to researchers' disinterest or lack of theoretical basis for the possible relationship between these variables. The main reason seems to be the fact that burnout and engagement have recently been introduced in the field of second language research; to be more precise their introduction in second language research dates back to early years of twenty-first century with the introduction of Maslach Burnout Inventory-Student Survey (MBI-SS) (Schaufeli, et al., 2002) which paved the way for the investigation of burnout in students.

However in the following an account of the conjectures about the possible relationship between motivation, burnout, and engagement has been provided. First and foremost, Crooks and Schmidt (1991; cited in Ellis, 2008), trying to define characteristics of motivated learners, have stated that "it is probably fair to say that teachers would describe a student as motivated if s/he becomes productively engaged in learning tasks, and sustains that engagement, without the need for continual encouragement or direction" (p. 480). Additionally, Ellis (2008), talking about the effects of motivation, has simply asserted that motivation affects the extent to which language learners persevere in learning, what kinds of behaviour they exert, and their actual achievement.

Last but not least, expectancy-value theories (e.g. Atkinson and Raynor, 1974; cited in Dornyei, 1998, p. 4) have also given testimony to the fact that motivation may lead to increased expectations of success through increased effort which would possibly increase the chances of the final success in performing language learning tasks (Dornyei, 1998). The characteristics of motivated behaviour and motivated learners such as increased effort (Atkinson and Raynor, 1974; cited in Dornyei, 1998, p. 4), productive and sustained engagement (Crooks and Schmidt, 1991; cited in Ellis, 2008), and perseverance (Ellis, 2008), seem to be similar to those characteristics mentioned for learners with high engagement (Schaufeli et al. 2002)

\section{Methodology}

\subsection{Participants}

The main participants of the study were 95 adult learners of English (60 males and 35 females) studying at 
Alavi, S. A. \& Abbasnia, S.

intermediate and upper-intermediate levels in language institutes in Zahedan and Lar (in Iran). The participants were studying in four language institutes in Zahedan and two language institutes in Lar and were from a variety of social backgrounds.

The sampling method for this study was convenience sampling, that is, the choice of participants to be included in the study was based on availability of ease of access, however, only those at intermediate and upper-intermediate levels of proficiency and between the age of 20 to 24 were included in the final sample so as to prevent the sample from becoming to heterogeneous.

Proficiency level of participants to be included in the sample of the study was decided with the help of their institutes, in addition, there was a self-rating scale where participants could indicate their level of proficiency based on certain criteria (such as the ability to use language in specific situations and for specific tasks) as indicated on the questionnaire, the self-rating scale was adapted from Dornyei and Taguchi (2010). Only those learners' which both based on institutes' evaluation and self-rating scale were at intermediate and upper-intermediate levels were included in the sample. In addition to the main participants, 40 intermediate and upper-intermediate level language learners (20 male and 20 female, aged 20 to 24) participated for piloting instruments used in the study.

\subsection{Instrumentation}

The instruments used in the study were as follows:

1. A self-rating scale (in Persian) for learners to indicate their proficiency levels adapted from Dornyei and Taguchi (2010).

2. A translated version of Gardner's Attitudes/Motivation Test Battery (AMTB) (a 104 item, six-point likert-scale questionnaire) (Gardner, 1985b).

AMTB measures factors related to motivation based on 12 subscales as follows:

1. Interest in Foreign Languages

2. Parental Encouragement

3. Motivational Intensity

4. English Class Anxiety

5. English Teacher Evaluation

6. Attitudes towards Learning English

7. Attitudes towards English-speaking people

8. Integrative Orientation

9. Desire to Learn English

10. English Course Evaluation

11. English Use Anxiety

12. Instrumental Orientation

In addition to these subscales, the sum of learners' scores on motivational intensity, attitudes towards learning English and desire to learn English are taken as an indicator of learners' actual motivation. 
AMTB was translated from the English version into Persian by the first author, afterwards, it was back-translated by a translator holding a BA in English Translation. The correspondence between the original and back-translated versions was testified by a third translator. The translated questionnaire was given to nine learners aging from 16 to 32 (3 females and 6 males) and their comments regarding vagueness or miscomprehensions were received. In addition, two language teachers and an institute manager reviewed the items and gave their comments. A Final version of the questionnaire was developed considering the comments received from the learners, teachers, and the institute manager, meanwhile, during this process, two translators were supervising the process so as to ensure that the semantic correspondence between the English version and the translated version has not been lost.

The final version of the translated questionnaire was piloted among a sample of 40 language learners (mentioned in the participants section), while the reliability of the original version of AMTB calculated using Cronbach alpha formula is .85 (Gardner, 1985b), the Cronbach alpha coefficient as an index of reliability for the translated version of AMTB was .82 based on this pilot study.

A questionnaire developed through translating MBI-SS (Shaufeli et al., 2002) and UWES-S (Shaufeli et al., 2002) and merging the items on the two instruments. MBI-SS is a 15 item 7-point likert-type questionnaire to measure burnout among students with three subscales. Five items measure exhaustion, four items measure cynicism, and six items measure reduced professional efficacy. UWES-S is a questionnaire for measuring learners' engagement, includes 14 items on a 7-point likert-scale with three subscales, five items to measure vigour, five items to measure dedication, and four items to measure absorption.

The items on MBI-SS and UWES-S were translated through a process similar to the process for translating AMTB. For piloting and final administration, the items on MBI-SS and UWES-S were consequently merged, similar to the study by Schaufeli et al. (2002), to avoid answering bias. Besides, the original 7-point scale was changed into a 6-point scale. The choice of a 6-point scale over a 7-point scale was due to the fact that when respondents are less motivated or don't want to invest much cognitive work they tend to choose the middle category as a neutral choice (Dornyei \& Taguchi, 2010).

Prior to administrations, the translated questionnaire was piloted among 40 learners. However the reliability indices for original MBI-SS and UWES-S have not been mentioned in the literature, the reliability index for the translated questionnaire used in this study, calculated using Cronbach alpha formula, turned out to be .86 which is an acceptable index of reliability. The final versions of the questionnaires used in the study along with their English versions can be found in the appendices.

\subsection{Data Collection Procedure}

Prior to administration, researchers had explained to institute staff and teachers how to guide learners on responding to questionnaire items and using self-rating scale. Afterwards, the questionnaires along with the self-rating scale (described in the instrumentation section) were handed out to the participants by institute staff. Participants were guided on responding to the questionnaire items and using self-rating scale by their teachers and institute staff. After receiving instruction on responding to the questionnaire items and using self-rating scale, participants could take the questionnaires home and return them the next session, so they could take enough time responding to the questionnaires' items.

\section{Results and Data Analysis}

The data for the present study were submitted to the Statistical Package for Social Sciences (SPSS) in order to be analysed. Table 1 presents the descriptive statistics for different subscales of AMTB, MBI-SS, and UWES-S. The alpha level for all of the analyses was decided to be .05 . 
Alavi, S. A. \& Abbasnia, S.

\section{Table 1}

Descriptive statistics for different subscales of AMTB, Individuals' Motivation, MBI-SS, and UWES-S

\begin{tabular}{lllll}
\hline \multicolumn{1}{c}{ Scales } & $N$ & Mean & SD \\
\hline \multirow{5}{*}{ Interest in Foreign Languages } & 95 & 46.72 & 10.712 \\
& Parental Encouragement & 95 & 32.63 & 10.085 \\
& Motivational Intensity & 95 & 40.36 & 5.973 \\
& English Class Anxiety & 95 & 32.65 & 8.571 \\
& English Teacher Evaluation & 95 & 35.38 & 5.537 \\
& Attitudes toward Learning English & 95 & 47.98 & 10.679 \\
& Attitudes toward English-speaking people & 95 & 33.36 & 8.240 \\
AMTB & Integrative Orientation & 95 & 19.89 & 3.866 \\
& Desire to Learn English & 95 & 48.03 & 11.397 \\
& English Course Evaluation & 95 & 46.52 & 10.661 \\
& English Use Anxiety & 95 & 31.02 & 7.619 \\
& Instrumental Orientation & 95 & 18.19 & 4.221 \\
& Learners' Individual Motivation & & & \\
& (Motivational Intensity, Desire to Learn English, and Attitudes & 95 & 88.34 & 14.519 \\
& towards Learning English) & & & \\
\hline & Exhaustion & 95 & 10.97 & 4.743 \\
Cynicism & 95 & 8.60 & 4.147 \\
MBI-SS & 95 & 16.32 & 5.370 \\
& Reduced Professional Efficacy & 95 & 35.88 & 11.639 \\
\hline Total Burnout (MBI-SS Total) & 95 & 21.73 & 4.806 \\
\hline
\end{tabular}

\subsection{Research Question 1}

Is there any statistically significant relationship between Iranian EFL Learners' motivation and their burnout?

Concerning the first research question, sum of the scores on Motivational Intensity, Desire to Learn English, and Attitudes towards Learning English subscales of AMTB which according to Gardner (1985b) indicate individuals' motivation was taken as an indicator of learners' motivation. The degree of relatedness between learners' burnout (based on their scores on MBI-SS) and their motivation was tested using Pearson's correlation. In addition to total burnout scores, the relationships between motivation and different subscales of burnout were also tested using Pearson's correlation. The results of Pearson's correlation as indicated in Table 2 reveal that there are statistically significant negative relationships between learners' motivation and burnout and also between motivation and subscales of burnout. All of the correlations were significant at $\mathrm{p} \leq .000$ which is smaller than our alpha level $(\mathrm{N}=95, \alpha=.05)$; hence the answer to our first research question is positive and we can reject the related null hypothesis.

Table 2

Pearson's Correlation between Individual Motivation \& Burnout \& its subscales $(N=95, \alpha=.05)$

\begin{tabular}{|c|c|c|c|c|c|c|c|c|}
\hline & \multicolumn{2}{|c|}{ Exhaustion } & \multicolumn{2}{|c|}{ Cynicism } & \multicolumn{2}{|c|}{$\begin{array}{l}\text { Reduced } \\
\text { Professional } \\
\text { Efficacy }\end{array}$} & \multicolumn{2}{|c|}{ Total Burnout } \\
\hline & $r$ & $p$ & $r$ & $p$ & $r$ & $p$ & $r$ & $p$ \\
\hline $\begin{array}{l}\text { Learners' } \\
\text { Individual } \\
\text { Motivation }\end{array}$ & -.56 & .000 & -.66 & .000 & -.71 & .000 & -.79 & .000 \\
\hline
\end{tabular}


4.2 Research Question 2

Is there any statistically significant relationship between Iranian EFL Learners' motivation and their engagement?

To answer the second research question, once again sum of the scores on Motivational Intensity, Desire to Learn English, and Attitudes towards Learning English subscales of AMTB was taken as an indicator of learners' motivation. Pearson's correlation was used to check the degree of relatedness between learners' motivation and their scores for engagement (and subscales of engagement) as gathered using UWES-S. Similar to the first research question, very high correlations were found. All of the correlations were significant at $\mathrm{p} \leq .000 \mathrm{which}$ is smaller than our alpha level $(\mathrm{N}=95, \alpha=.05)$, so the related null hypothesis was successfully rejected. Table 3 presents the correlations between learners' motivation and engagement and also motivation and subscales of engagement.

Table 3

Pearson's Correlation between Individual Motivation \& Engagement \& its subscales $(N=95, \alpha=.05)$

\begin{tabular}{lllllllll}
\hline & \multicolumn{1}{c}{ Vigour } & \multicolumn{3}{c}{ Dedication } & \multicolumn{2}{c}{ Absorption } & \multicolumn{2}{c}{ Total Engagement } \\
\cline { 2 - 9 } & $r$ & $p$ & $r$ & $p$ & $r$ & $p$ & $r$ & $p$ \\
\hline $\begin{array}{l}\text { Learners' } \\
\text { Individual } \\
\text { Motivation }\end{array}$ & .58 & .000 & .68 & .000 & .51 & .000 & .69 & .000 \\
\hline
\end{tabular}

\subsection{Research Question 3}

Is there any statistically significant relationship between subscales of AMTB and burnout of Iranian EFL Learners?

Considering the third research question, analysis of the relationships between the 12 subscales of AMTB and burnout using Pearson's correlation indicated that all of the subscales of AMTB are significantly related to burnout and our third hypothesis was successfully rejected $(\mathrm{N}=95, \alpha=.05)$. However, when we look at the table of correlations we find out that all of the subscales of AMTB are negatively correlated with burnout except English class anxiety and English use anxiety which are positively correlated with burnout. This reveals that while interest, positive attitudes, encouragement from parents, etc. may be the opposites of burnout, there may be some direct links between anxiety and burnout. Table 4 shows the correlations between the subscales of AMTB and burnout.

\section{Table 4}

Results of Pearson's Correlation between subscales of AMTB and Burnout $(N=95, \alpha=.05)$

\begin{tabular}{lcc}
\hline \multicolumn{1}{c}{ Subscales of AMTB } & \multicolumn{2}{c}{ Burnout } \\
\cline { 2 - 3 } & \multicolumn{1}{c}{$p$} & .000 \\
\hline Interest in Foreign Languages & -.74 & .002 \\
Parental Encouragement & -.32 & .000 \\
Motivational Intensity & -.54 & .001 \\
English Class Anxiety & .32 & .004 \\
English Teacher Evaluation & -.29 & .000 \\
Attitudes toward Learning English & -.78 & .000 \\
Attitudes toward English-speaking people & -.40 & .000 \\
Integrative Orientation & -.56 & .000 \\
Desire to Learn English & -.78 & .000 \\
English Course Evaluation & -.78 & .000 \\
English Use Anxiety & .35 & .001 \\
Instrumental Orientation & -.33 & \\
\hline
\end{tabular}


Alavi, S. A. \& Abbasnia, S.

4.4 Research Question 4

Is there any statistically significant relationship between subscales of AMTB and engagement of Iranian EFL Learners?

Similar to the previous research questions, for answering the fourth research question, Pearson's correlation was our statistic of choice. Results of the analysis revealed that all of the 12 subscales of AMTB were significantly and positively related to engagement except English class anxiety and English use anxiety where no significant relationships $(\mathrm{N}=95, \alpha=.05)$ between these two and engagement was observed. 10 out of the 12 correlations were significant at $\mathrm{p} \leq .05$ which means that our fourth null hypothesis was partly rejected $(\mathrm{N}=95$, $\alpha=.05$ ). The detailed results can be found in Table 5 .

Table 5

Results of Pearson's Correlation between subscales of AMTB and Engagement $(N=95, \alpha=.05)$

\begin{tabular}{lcc}
\hline \multicolumn{1}{c}{ Subscales of AMTB } & \multicolumn{2}{c}{ Engagement } \\
\cline { 2 - 3 } & $r$ & $p$ \\
\hline Interest in Foreign Languages & $\mathbf{. 6 3}$ & .000 \\
Parental Encouragement & $\mathbf{. 5 3}$ & .000 \\
Motivational Intensity & $\mathbf{. 5 6}$ & .000 \\
English Class Anxiety & -.14 & .158 \\
English Teacher Evaluation & $\mathbf{. 4 2}$ & .000 \\
Attitudes toward Learning English & $\mathbf{. 6 2}$ & .000 \\
Attitudes toward English-speaking people & $\mathbf{. 5 0}$ & .000 \\
Integrative Orientation & $\mathbf{. 6 1}$ & .000 \\
Desire to Learn English & $\mathbf{. 6 6}$ & .000 \\
English Course Evaluation & $\mathbf{. 6 2}$ & .000 \\
English Use Anxiety & -.17 & .083 \\
Instrumental Orientation & $\mathbf{. 4 2}$ & .000 \\
\hline
\end{tabular}

Note. Boldfaced correlations are significant at $p<.05$

\section{Discussion and Conclusion}

The results of the present study indicate that there is a negative correlation between different subscales of motivation and burnout and a positive correlation between different subscales of motivation and engagement. In what follows theoretical and pedagogical implications of the study have been discussed and suggestions for further research have been provided.

\subsection{Theoretical and Pedagogical Implications of the Study}

Results of the first and second research questions reveal the validity of the claims made by those such as Crooks and Schmidt (1991), Ellis (2008), and Atkinson and Raynor (1974) regarding the idea that motivated learners can be more engaged, more persevering and invest more effort in performing language learning tasks. The findings revealed that motivation among learners is greatly correlated with the three subscales of engagement, i.e. vigour, dedication, and absorption. On the contrary, based on the findings of this study, an increase in learners' motivation may be synonymous with a decrease in their burnout and also in all of the subscales of burnout, i.e. exhaustion, cynicism, and reduced efficacy. Additionally, results of the third and fourth research questions shed more light on the issue by revealing the fact that not only learners' individual motivation but also different factors that affect learners' motivation in general, such as parental encouragement or teacher evaluation are also highly correlated with burnout and engagement among learners.

Based on the relationship found between burnout and motivation and the characterisations of burnout (Schaufeli et al., 2002), the findings imply that motivated learners would be expected to be less exhausted in language learning, don't have distant attitudes towards learning activities and show more professional efficacy 
Motivation and motivation-related factors and their relationship with burnout and engagement

due to their educational accomplishments. Additionally, based on the characterisations of engagement (Schaufeli et al., 2002) and with respect to the relationship discovered between motivation and engagement, motivated learners would be expected to show high levels of energy, mental resilience and ability to invest effort in their learning, meanwhile, they would possibly be more enthusiastic and proud about their language learning, ready to face challenges and would be fully engrossed in their work.

The fact that motivation and motivation-related factors can be germane to burnout and engagement among language learners, two variables which according to Langroudi and Pirouznejad (2013) are related to one's academic success, once again, echo the importance of motivation in language learning and teaching. Teachers should be informed about different factors which may increase learners' motivation, such as anxiety, interest in foreign languages, attitudes towards foreign languages, etc. They should also inform parents of the importance of parental encouragement as a factor affecting learners' motivation. In a broader sense, not only teachers, but also syllabus designers and curriculum developers should also keep these findings in mind since much of what happens in any language program is mainly dependent upon higher-level decisions made about course values and contents which may positively affect variables such as learners' attitudes towards foreign languages and foreign language speakers, general evaluations of language courses, development of instrumental and integrative orientations in learners, etc. which according to Gardner (1985a) would consequently affect learners' motivation.

In addition, Dornyei (1994) has introduced several ways for increasing learners' motivation such as including sociocultural components within a course, promoting contact with second language speakers, making syllabus of the course relevant through needs analyses, etc. which can provide starting points for the decision making of teachers, syllabus designers, and curriculum developers in this regard. Dornyei and Csizer (1998) have also enumerated several macrostrategies to be used by teachers for increasing learners' motivation such as promoting learner autonomy, increasing learners' goal-orientedness, familiarizing learners' with the target language culture, etc. However implementation of such strategies also requires efforts not only from teachers but also from teacher educators, syllabus designers and curriculum developers. These groups may take the above mentioned ways into consideration so as to improve learners' motivation which may result in decreased burnout and increased engagement among learners. It's hoped that this decrease in burnout and increase in engagement would positively affect learners' achievement as demonstrated by Langroudi and Pirouznejad (2013).

\subsection{Suggestions for Further Research}

The fact that motivation and its subscales are germane to burnout and engagement, two variables which according to Langroudi and Pirouznejad (2013) are related to one's academic success, gives clear hints to all of those involved in second language teaching and research to pay more attention to these variables. Further research is necessary to investigate the links between these variables in detail. This is also necessary to mention that the present study mainly rests upon Gardner's model for motivation, while further studies with a focus on Dornyei's model for motivation may also be beneficial to revealing more facts about the aforementioned relations and throwing more light on the issue.

\section{References:}

Atkinson, J. W., \& Raynor, J. O. (1974). Motivation and achievement. Washington, DC: Winston \& Sons.

Crooks, G., \& Schmidt, R. (1991). Language learning motivation: reporting the research agenda. Language Learning, 41, 469-512. http://dx.doi.org/10.1111/j.1467-1770.1991.tb00690.x

Dornyei, Z., \& Taguchi, T. (2010). Questionnaires in second language acquisition (2nd ed.). London: Routledge.

Dornyei, Z. (1994). Motivation and motivating in the foreign language classroom. Modern Language Journal, 78(3), 273-284. http://dx.doi.org/10.1111/j.1540-4781.1994.tb02042.x

Dornyei, Z. (1998). Motivation in second and foreign language learning. Language Teaching, 31, 117-135. http://dx.doi.org/10.1017/S026144480001315X

Dornyei, Z., \& Csizer, K. (1998). Ten commandments for motivating language learners: results of an empirical 
Alavi, S. A. \& Abbasnia, S.

study. Language Teaching Research, 2(3), 203-229.

Ellis, R. (2008). The study of second language acquisition (2nd ed.). Oxford: Oxford University Press.

Freudenberger, H. J. (1974). Staff burnout. Journal of Social Issues, 30, 159-165.

http://dx.doi.org/10.1111/j.1540-4560.1974.tb00706.x

Gardner, R. C. (1985a). Social psychology and second language learning: The role of attitudes and motivation. London: Edward Arnold.

Gardner, R. C. (1985b). The attitudes/motivation test battery: Technical report. London: University of Western Ontario Press.

Langroudi, J., \& Pirouznejad, M. (2013). The relationship of burnout, engagement, and employment with academic achievement of Iranian EFL university students. Iranian EFL Journal, 9(1), 300-314.

Richards, J. C., \& Schmidt, R. W. (2002). Dictionary of language teaching \& applied linguistics (3rd ed.). Harlow: Longman.

Root, E. (1995). Motivation and learning strategies in a foreign language setting: A look at a learner of Korean. Unpublished Manuscript, Centre for Advanced Research on Language Acquisition, University of Minnesota, MN, United States.

Schaufeli, W.B., Martínez, I., Marques Pinto, A., Salanova, M., \& Bakker, A.B. (2002). Burnout and engagement in university students: A cross national study. Journal of Cross-Cultural Psychology, 33, 464-481. http://dx.doi.org/10.1177/0022022102033005003

Schaufeli,W. B., Leiter,M. P., Maslach, C., \& Jackson, S. E. (1996). Maslach burnout inventory-general survey. In C. Maslach, S. E. Jackson, \& M. P. Leiter (Eds.), The Maslach Burnout Inventory-Test manual (3rd ed.). Palo Alto, CA: Consulting Psychologists Press.

\section{Appendix A: Merged version of MBI-SS and UWES-S (in English)}

Please indicate whether you agree or disagree with the following statements, mark the statements based on the key below. Key:

\begin{tabular}{|c|c|c|c|c|c|}
\hline 1 & 2 & 3 & 4 & 5 & 6 \\
Strongly Disagree & Disagree & Almost Disagree & Almost Agree & Agree & Strongly Agree \\
\hline
\end{tabular}

\begin{tabular}{|c|c|c|c|c|c|c|c|}
\hline 1 & I find my studies challenging. & 1 & 2 & 3 & 4 & 5 & 6 \\
\hline 2 & When I am studying, I forget everything else around me. & 1 & 2 & 3 & 4 & 5 & 6 \\
\hline 3 & I feel emotionally drained by my studies. & 1 & 2 & 3 & 4 & 5 & 6 \\
\hline 4 & I feel tired when I get up in the morning and I have to face another day at the university. & 1 & 2 & 3 & 4 & 5 & 6 \\
\hline 5 & I feel stimulated when I achieve my study goals. & 1 & 2 & 3 & 4 & 5 & 6 \\
\hline 6 & When I'm studying, I feel mentally strong. & 1 & 2 & 3 & 4 & 5 & 6 \\
\hline 7 & Time flies when I'm studying. & 1 & 2 & 3 & 4 & 5 & 6 \\
\hline 8 & I can get carried away by my studies. & 1 & 2 & 3 & 4 & 5 & 6 \\
\hline 9 & I doubt the significance of my studies. & 1 & 2 & 3 & 4 & 5 & 6 \\
\hline 10 & When studying I feel strong and vigorous. & 1 & 2 & 3 & 4 & 5 & 6 \\
\hline 11 & I feel burned out from my studies. & 1 & 2 & 3 & 4 & 5 & 6 \\
\hline 12 & My studies inspire me. & 1 & 2 & 3 & 4 & 5 & 6 \\
\hline 13 & I can effectively solve the problems that arise in my studies. & 1 & 2 & 3 & 4 & 5 & 6 \\
\hline 14 & I can continue for a very long time when I am studying. & 1 & 2 & 3 & 4 & 5 & 6 \\
\hline 15 & I have become less enthusiastic about my studies. & 1 & 2 & 3 & 4 & 5 & 6 \\
\hline 16 & I am proud of my studies. & 1 & 2 & 3 & 4 & 5 & 6 \\
\hline 17 & In my opinion, I am a good student. & 1 & 2 & 3 & 4 & 5 & 6 \\
\hline 18 & I have become less interested in my studies since my enrollment at the university. & 1 & 2 & 3 & 4 & 5 & 6 \\
\hline 19 & I am enthusiastic about my studies. & 1 & 2 & 3 & 4 & 5 & 6 \\
\hline 20 & During class I feel confident that I am effective in getting things done. & 1 & 2 & 3 & 4 & 5 & 6 \\
\hline 21 & I have become more cynical about the potential usefulness of my studies. & 1 & 2 & 3 & 4 & 5 & 6 \\
\hline 22 & I feel happy when I am studying intensively. & 1 & 2 & 3 & 4 & 5 & 6 \\
\hline 23 & When I study, I feel like I am bursting with energy. & 1 & 2 & 3 & 4 & 5 & 6 \\
\hline 24 & I feel tired when I get up in the morning and I have to face another day at the university. & 1 & 2 & 3 & 4 & 5 & 6 \\
\hline 25 & I have learned many interesting things during the course of my studies. & 1 & 2 & 3 & 4 & 5 & 6 \\
\hline 26 & I find my studies to be full of meaning and purpose. & 1 & 2 & 3 & 4 & 5 & 6 \\
\hline 27 & When I get up in the morning, I feel like going to class. & 1 & 2 & 3 & 4 & 5 & 6 \\
\hline 28 & I feel used up at the end of a day at university. & 1 & 2 & 3 & 4 & 5 & 6 \\
\hline 28 & I believe that I make an effective contribution to the classes that I attend. & 1 & 2 & 3 & 4 & 5 & 6 \\
\hline
\end{tabular}


Motivation and motivation-related factors and their relationship with burnout and engagement

Appendix B: Key to the merged version of MBI-SS and UWES-S

\begin{tabular}{|l|l|l|l|}
\hline No & Scale & Positively Keyed & Negatively Keyed \\
\hline MBI-SS & \multicolumn{2}{l|}{} \\
\hline 1 & Exhaustion & $3-4-11-24-28$ & \\
\hline 2 & Cynicism & $9-15-18-21$ & \\
\hline 3 & Professional Efficacy & & $5-13-17-20-25-29$ \\
\hline UWES-S & & \\
\hline 4 & Vigour & $6-10-14-23-27$ & \\
\hline 5 & Dedication & $1-12-16-19-26$ & \\
\hline 6 & Absorption & $2-7-8-22$ & \\
\hline
\end{tabular}

\section{Appendix C: English AMTB (Gardner, 1985b)}

Please indicate whether you agree or disagree with the following statements, mark the statements based on the key below. Key:

\begin{tabular}{|c|c|c|c|c|c|}
\hline 1 & 2 & 3 & 4 & 5 & 6 \\
Strongly Disagree & Disagree & Almost Disagree & Almost Agree & Agree & Strongly Agree \\
\hline
\end{tabular}

\begin{tabular}{|c|c|c|c|c|c|c|c|}
\hline 1 & I wish I could speak many foreign languages perfectly. & 1 & 2 & 3 & 4 & 5 & 6 \\
\hline 2 & My parents try to help me to learn English. & 1 & 2 & 3 & 4 & 5 & 6 \\
\hline 3 & I don't pay much attention to the feedback I receive in my English class. & 1 & 2 & 3 & 4 & 5 & 6 \\
\hline 4 & I don't get anxious when I have to answer a question in my English class. & 1 & 2 & 3 & 4 & 5 & 6 \\
\hline 5 & I look forward to going to class because my English teacher is so good. & 1 & 2 & 3 & 4 & 5 & 6 \\
\hline 6 & Learning English is really great. & 1 & 2 & 3 & 4 & 5 & 6 \\
\hline 7 & If Japan had no contact with English-speaking countries, it would be a great loss. & 1 & 2 & 3 & 4 & 5 & 6 \\
\hline 8 & $\begin{array}{l}\text { Studying English is important because it will allow me to be more at ease with people who } \\
\text { speak English. }\end{array}$ & 1 & 2 & 3 & 4 & 5 & 6 \\
\hline 9 & I have a strong desire to know all aspects of English. & 1 & 2 & 3 & 4 & 5 & 6 \\
\hline 10 & My English class is really a waste of time. & 1 & 2 & 3 & 4 & 5 & 6 \\
\hline 11 & I would get nervous if I had to speak English to a tourist. & 1 & 2 & 3 & 4 & 5 & 6 \\
\hline 12 & Studying foreign languages is not enjoyable. & 1 & 2 & 3 & 4 & 5 & 6 \\
\hline 13 & I make a point of trying to understand all the English I see and hear. & 1 & 2 & 3 & 4 & 5 & 6 \\
\hline 14 & I don't think my English teacher is very good. & 1 & 2 & 3 & 4 & 5 & 6 \\
\hline 15 & Studying English is important because I will need it for my career. & 1 & 2 & 3 & 4 & 5 & 6 \\
\hline 16 & I never feel quite sure of myself when I am speaking in our English class. & 1 & 2 & 3 & 4 & 5 & 6 \\
\hline 17 & Knowing English isn't really an important goal in my life. & 1 & 2 & 3 & 4 & 5 & 6 \\
\hline 18 & I hate English. & 1 & 2 & 3 & 4 & 5 & 6 \\
\hline 19 & I feel very much at ease when I have to speak English. & 1 & 2 & 3 & 4 & 5 & 6 \\
\hline 20 & I would rather spend more time in my English class and less in other classes. & 1 & 2 & 3 & 4 & 5 & 6 \\
\hline 21 & I wish I could read newspapers and magazines in many foreign languages. & 1 & 2 & 3 & 4 & 5 & 6 \\
\hline 22 & My parents feel that it is very important for me to learn English. & 1 & 2 & 3 & 4 & 5 & 6 \\
\hline 23 & I don't bother checking my assignments when I get them back from my English teacher. & 1 & 2 & 3 & 4 & 5 & 6 \\
\hline 24 & I feel confident when asked to speak in my English class. & 1 & 2 & 3 & 4 & 5 & 6 \\
\hline 25 & My English teacher is better than any of my other teachers. & 1 & 2 & 3 & 4 & 5 & 6 \\
\hline 26 & I really enjoy learning English. & 1 & 2 & 3 & 4 & 5 & 6 \\
\hline 27 & $\begin{array}{l}\text { Most native English speakers are so friendly and easy to get along with, we are fortunate to } \\
\text { have them as friends. }\end{array}$ & 1 & 2 & 3 & 4 & 5 & 6 \\
\hline 28 & $\begin{array}{l}\text { Studying English is important because it will allow me to meet and converse with more and } \\
\text { varied people. }\end{array}$ & 1 & 2 & 3 & 4 & 5 & 6 \\
\hline 29 & If it were up to me, I would spend all of my time learning English. & 1 & 2 & 3 & 4 & 5 & 6 \\
\hline 30 & I think my English class is boring. & 1 & 2 & 3 & 4 & 5 & 6 \\
\hline 31 & Speaking English anywhere makes me feel worried. & 1 & 2 & 3 & 4 & 5 & 6 \\
\hline 32 & I really have no interest in foreign languages. & 1 & 2 & 3 & 4 & 5 & 6 \\
\hline 33 & I keep up to date with English by working on it almost every day. & 1 & 2 & 3 & 4 & 5 & 6 \\
\hline 34 & The less I see of my English teacher, the better. & 1 & 2 & 3 & 4 & 5 & 6 \\
\hline 35 & Studying English is important because it will make me more educated. & 1 & 2 & 3 & 4 & 5 & 6 \\
\hline 36 & It embarrasses me to volunteer answers in our English class. & 1 & 2 & 3 & 4 & 5 & 6 \\
\hline 37 & I sometimes daydream about dropping English. & 1 & 2 & 3 & 4 & 5 & 6 \\
\hline 38 & I would rather spend my time on subjects other than English. & 1 & 2 & 3 & 4 & 5 & 6 \\
\hline 39 & It doesn't bother me at all to speak English. & 1 & 2 & 3 & 4 & 5 & 6 \\
\hline 40 & I wish I could have many native English speaking friends. & 1 & 2 & 3 & 4 & 5 & 6 \\
\hline 41 & I enjoy the activities of our English class much more than those of my other classes. & 1 & 2 & 3 & 4 & 5 & 6 \\
\hline 42 & I would really like to learn many foreign languages. & 1 & 2 & 3 & 4 & 5 & 6 \\
\hline 43 & My parents feel that I should continue studying English all through school. & 1 & 2 & 3 & 4 & 5 & 6 \\
\hline 44 & I put off my English homework as much as possible. & 1 & 2 & 3 & 4 & 5 & 6 \\
\hline 45 & I am calm whenever I have to speak in my English class. & 1 & 2 & 3 & 4 & 5 & 6 \\
\hline
\end{tabular}


Alavi, S. A. \& Abbasnia, S.

\begin{tabular}{|c|c|c|c|c|c|c|c|}
\hline 46 & My English teacher has a dynamic and interesting teaching style. & 1 & 2 & 3 & 4 & 5 & 6 \\
\hline 47 & English is a very important part of the school program. & 1 & 2 & 3 & 4 & 5 & 6 \\
\hline 48 & My parents have stressed the importance English will have for me when I leave school. & 1 & 2 & 3 & 4 & 5 & 6 \\
\hline 49 & Native English speakers are very sociable and kind. & 1 & 2 & 3 & 4 & 5 & 6 \\
\hline 50 & $\begin{array}{l}\text { Studying English is important because it will enable me to better understand and appreciate the } \\
\text { English way of life. }\end{array}$ & 1 & 2 & 3 & 4 & 5 & 6 \\
\hline 51 & I want to learn English so well that it will become natural to me. & 1 & 2 & 3 & 4 & 5 & 6 \\
\hline 52 & To be honest, I really have little interest in my English class. & 1 & 2 & 3 & 4 & 5 & 6 \\
\hline 53 & $\begin{array}{l}\text { Native English speakers have much to be proud about because they have given the world much } \\
\text { of value. }\end{array}$ & 1 & 2 & 3 & 4 & 5 & 6 \\
\hline 54 & It would bother me if I had to speak English on the telephone. & 1 & 2 & 3 & 4 & 5 & 6 \\
\hline 55 & It is not important for us to learn foreign languages. & 1 & 2 & 3 & 4 & 5 & 6 \\
\hline 56 & $\begin{array}{l}\text { When I have a problem understanding something in my English class, I always my teacher for } \\
\text { help. }\end{array}$ & 1 & 2 & 3 & 4 & 5 & 6 \\
\hline 57 & My parents urge me to seek help from my teacher if I am having problems with my English. & 1 & 2 & 3 & 4 & 5 & 6 \\
\hline 58 & My English teacher is one of the least pleasant people I know. & 1 & 2 & 3 & 4 & 5 & 6 \\
\hline 59 & Studying English is important because it will be useful in getting a good job. & 1 & 2 & 3 & 4 & 5 & 6 \\
\hline 60 & It worries me that other students in my class seem to speak English better than I do. & 1 & 2 & 3 & 4 & 5 & 6 \\
\hline 61 & I'm losing any desire I ever had to know English. & 1 & 2 & 3 & 4 & 5 & 6 \\
\hline 62 & Learning English is a waste of time. & 1 & 2 & 3 & 4 & 5 & 6 \\
\hline 63 & I would feel quite relaxed if I had to give street directions in English. & 1 & 2 & 3 & 4 & 5 & 6 \\
\hline 64 & I like my English class so much, I look forward to studying more English in the future. & 1 & 2 & 3 & 4 & 5 & 6 \\
\hline 65 & If I planned to stay in another country, I would try to learn their language. & 1 & 2 & 3 & 4 & 5 & 6 \\
\hline 66 & My parents are very interested in everything I do in my English class. & 1 & 2 & 3 & 4 & 5 & 6 \\
\hline 67 & $\begin{array}{l}\text { I tend to give up and not pay attention when I don't understand my English teacher's } \\
\text { explanation of something. }\end{array}$ & 1 & 2 & 3 & 4 & 5 & 6 \\
\hline 68 & I don't understand why other students feel nervous about speaking English in class. & 1 & 2 & 3 & 4 & 5 & 6 \\
\hline 69 & My English teacher is a great source of inspiration to me. & 1 & 2 & 3 & 4 & 5 & 6 \\
\hline 70 & I plan to learn as much English as possible. & 1 & 2 & 3 & 4 & 5 & 6 \\
\hline 71 & I would like to know more native English speakers. & 1 & 2 & 3 & 4 & 5 & 6 \\
\hline 72 & $\begin{array}{l}\text { Studying English is important because I will be able to interact more easily with speakers of } \\
\text { English. }\end{array}$ & 1 & 2 & 3 & 4 & 5 & 6 \\
\hline 73 & I would like to learn as much English as possible. & 1 & 2 & 3 & 4 & 5 & 6 \\
\hline 74 & To be honest, I don't like my English class. & 1 & 2 & 3 & 4 & 5 & 6 \\
\hline 75 & I would feel uncomfortable speaking English anywhere outside the classroom. & 1 & 2 & 3 & 4 & 5 & 6 \\
\hline 76 & Most foreign languages sound crude and harsh. & 1 & 2 & 3 & 4 & 5 & 6 \\
\hline 77 & I really work hard to learn English. & 1 & 2 & 3 & 4 & 5 & 6 \\
\hline 78 & I would prefer to have a different English teacher. & 1 & 2 & 3 & 4 & 5 & 6 \\
\hline 79 & Studying English is important because other people will respect me more if I know English. & 1 & 2 & 3 & 4 & 5 & 6 \\
\hline 80 & I get nervous when I am speaking in my English class. & 1 & 2 & 3 & 4 & 5 & 6 \\
\hline 81 & To be honest, I really have no desire to learn English. & 1 & 2 & 3 & 4 & 5 & 6 \\
\hline 82 & I think that learning English is dull. & 1 & 2 & 3 & 4 & 5 & 6 \\
\hline 83 & $\begin{array}{l}\text { I would feel comfortable speaking English where both Japanese and English speakers } \\
\text { present. }\end{array}$ & 1 & 2 & 3 & 4 & 5 & 6 \\
\hline 84 & I look forward to the time I spend in English class. & 1 & 2 & 3 & 4 & 5 & 6 \\
\hline 85 & I enjoy meeting people who speak foreign languages. & 1 & 2 & 3 & 4 & 5 & 6 \\
\hline 86 & My parents encourage me to practice my English as much as possible. & 1 & 2 & 3 & 4 & 5 & 6 \\
\hline 87 & I can't be bothered trying to understand the more complex aspects of English. & 1 & 2 & 3 & 4 & 5 & 6 \\
\hline 88 & Students who claim they get nervous in English classes are just making excuses. & 1 & 2 & 3 & 4 & 5 & 6 \\
\hline 89 & I really like my English teacher. & 1 & 2 & 3 & 4 & 5 & 6 \\
\hline 90 & I love learning English. & 1 & 2 & 3 & 4 & 5 & 6 \\
\hline 91 & The more I get to know native English speakers, the more I like them. & 1 & 2 & 3 & 4 & 5 & 6 \\
\hline 92 & I wish I were fluent in English. & 1 & 2 & 3 & 4 & 5 & 6 \\
\hline 93 & I have a hard time thinking of anything positive about my English class. & 1 & 2 & 3 & 4 & 5 & 6 \\
\hline 94 & I feel anxious if someone asks me something in English. & 1 & 2 & 3 & 4 & 5 & 6 \\
\hline 95 & $\begin{array}{l}\text { I would rather see a TV program dubbed into our language than in its own language with } \\
\text { subtitles. }\end{array}$ & 1 & 2 & 3 & 4 & 5 & 6 \\
\hline 96 & When I am studying English, I ignore distractions and pay attention to my task. & 1 & 2 & 3 & 4 & 5 & 6 \\
\hline 97 & My English teacher doesn't present materials in an interesting way. & 1 & 2 & 3 & 4 & 5 & 6 \\
\hline 98 & I am sometimes anxious that the other students in class will laugh at me when I speak English. & 1 & 2 & 3 & 4 & 5 & 6 \\
\hline 99 & I haven't any great wish to learn more than the basics of English. & 1 & 2 & 3 & 4 & 5 & 6 \\
\hline 100 & When I leave school, I will give up the study of English because I am not interested in it. & 1 & 2 & 3 & 4 & 5 & 6 \\
\hline 101 & I would feel calm and sure of myself if I had to order a meal in English. & 1 & 2 & 3 & 4 & 5 & 6 \\
\hline 102 & English is one of my favorite courses. & 1 & 2 & 3 & 4 & 5 & 6 \\
\hline 103 & My parents think I should devote more time to studying English. & 1 & 2 & 3 & 4 & 5 & 6 \\
\hline 104 & You can always trust native English speakers. & 1 & 2 & 3 & 4 & 5 & 6 \\
\hline
\end{tabular}

